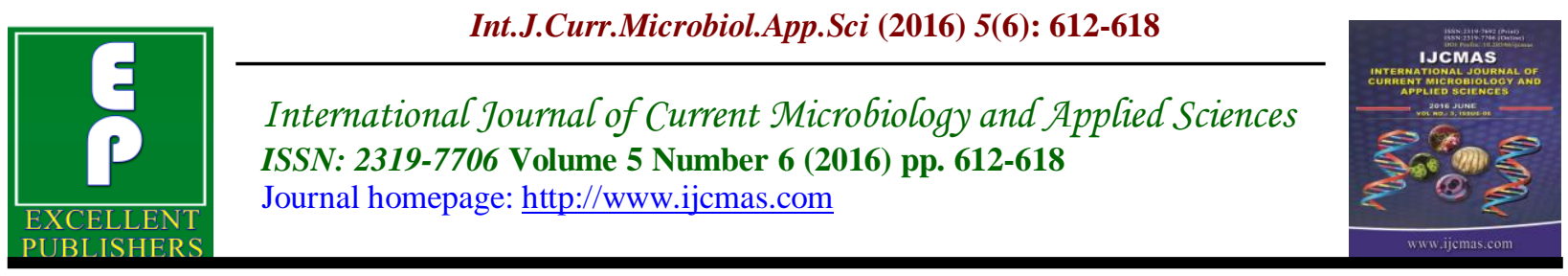

Case Study

http://dx.doi.org/10.20546/ijcmas.2016.506.066

\title{
HPV Positive, I am not sick!, Who did you get? Its Impact on the Health of the Patient
}

\author{
Mónica Luz Cabrera López ${ }^{1}$, Verónica Rodríguez Galicia ${ }^{1}$, Patricia Vázquez Alvarado ${ }^{2}$, \\ Diana Verónica Sánchez Martínez ${ }^{3}$, Jesús Carlos Ruvalcaba Ledezma ${ }^{4} *$ \\ ${ }^{1}$ Laboratorio de Microbiología del Instituto Nacional de Cardiología, México. \\ ${ }^{2}$ Investigador de Tiempo Completo en Área Académica de Odontología [ICSa-UAEH]. Instituto \\ de Ciencias de la Salud-Universidad Autónoma del Estado de Hidalgo, México. \\ ${ }^{3}$ Profesor en Escuela Superior de Atotonilco de Tula[UAEH]. Universidad Autónoma del Estado \\ de Hidalgo, México. \\ 4*Investigador de Tiempo Completo en Área Académica de Medicina. Maestría en Salud Pública \\ [ICSa-UAEH]. Instituto de Ciencias de la Salud-Universidad Autónoma del Estado de Hidalgo, \\ México. \\ *Corresponding author email id:
}

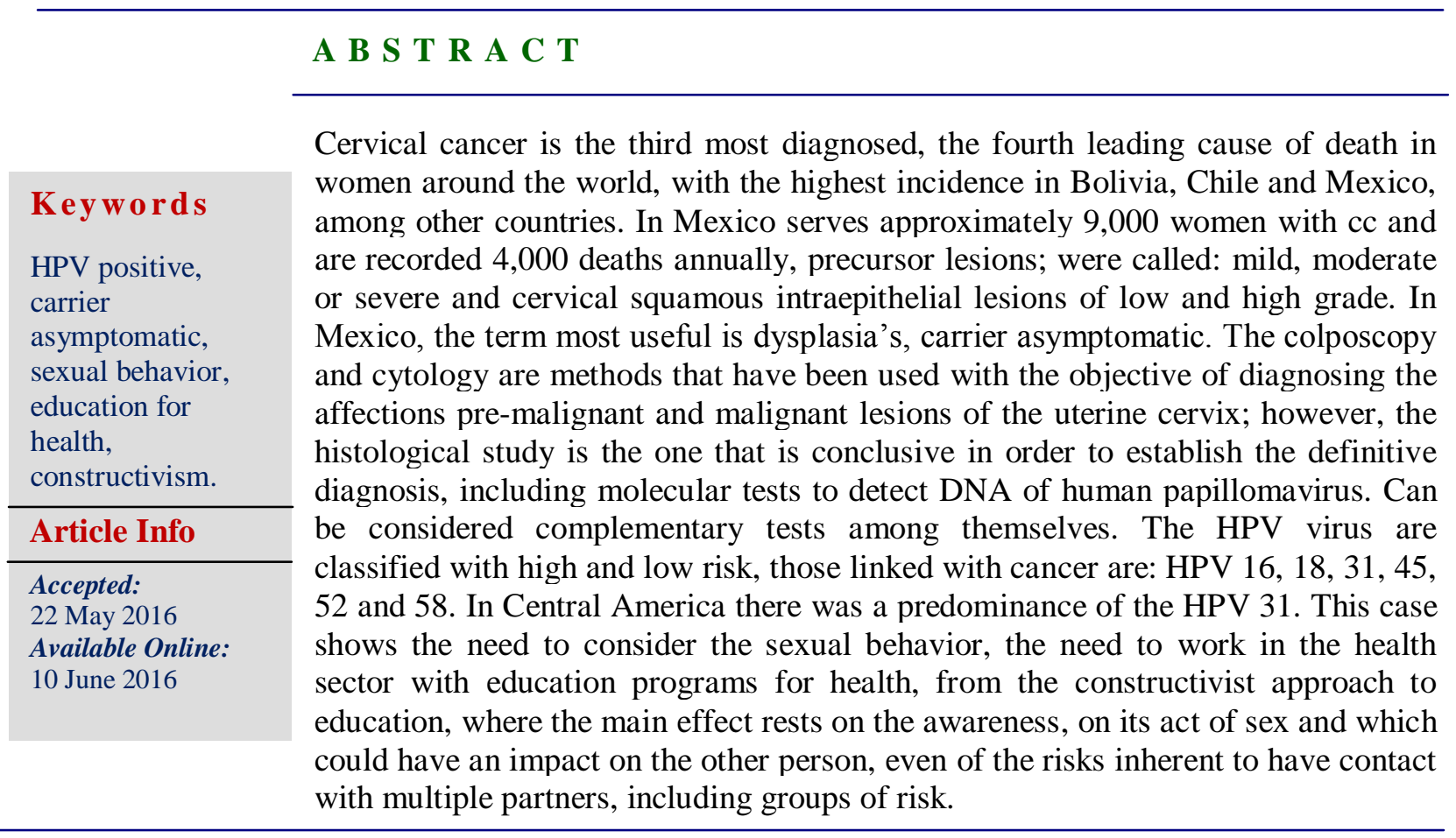

\section{Introduction}

Cervical cancer is the third type of cancer most commonly diagnosed, the fourth leading cause of death in women around the world, approximately 275000 in 2008 . The highest incidence rates are found in Africa, Asia, Central and South America, the lowest rates in Australia, New Zealand and North 
America (Ahmedin Jemal D.V.M. et al., 2011). The highest rates were observed in Bolivia, Chile and Mexico, as well as Peru, Brazil, Paraguay, Colombia and Costa Rica, were reported lower rates in Puerto Rico and Cuba (Serrano L., D., et al. 2012). In Mexico provides medical care to approximately 9,000 women with cc and are recorded 4,000 deaths annually. In 2008 was reported an incidence rate of 19.2 and mortality of $9.7 / 100,000$ women, the high incidence of $\mathrm{CC}$ is due in large part to lack of screening tests (Serrano L., D., et al. 2012) (Sánchez Barriga J.J. 2012).

One of the most important developments is the identification of precursor lesions, which have been the subject of different classifications. The first classification was performed in 1930 and appointed with the term of dysplasia. According to their seriousness is called: mild, moderate, or severe. In 1968 was coined the concept of Cervical Intraepithelial Neoplasia (CIN), with different degrees: NIC I, CIN II and CIN III or carcinoma in situ (Hadzic B., et al.1999) (Broso P.R \&Buffetti G., 1993). The concept of squamous intraepithelial lesions, subdividing in low-grade squamous intraepithelial lesions (LSIL) and squamous intraepithelial lesions of high grade (HSIL). In the LSIL are including infections by human papillomavirus (HPV) and mild dysplasia or CIN I. The dysplasias moderate and severe or NIC IIIII are grouped together in the HSIL (Broso P.R. and Buffetti G., 1993). The meaning that these cells have in the development of cervical pathology, it is not yet clear (Cox J.T., 1999) (Cox JT, et al., 1995). In Mexico, the classification used is one that uses the term dysplasia (NOM014-SSA2-1994, 1998).

The colposcopy is an optical method of viewing the female genital tract less under bright lighting under stereoscopic vision. It is a simple procedure, non-invasive test that aid in the determination of the location, size and extension of the cervical lesions abnormal and serves to detect the site for biopsies and to select the most appropriate treatment (Sánchez Barriga J.J. 2012).

The purpose of the PAP and the colposcopy, is to resolve a large group of healthy people the chance of having the disease, evaluating the effectiveness diagnosed between (PAP) Pap smear and colposcopy (Hadzic B,et al.1999). A colposcopy is a routine method in centers cancerológicos where performed tests of gynecological diseases, this method was established by Dr. Hinselmann of Hamburg in 1928 and since then has been well used, initially used appliances monoculars that increased from 10 to 20 diameters, then with the colposcope until 40 increases (Graham F.J.C., 1959).

The cervico-vaginal cytology, colposcopy, histopathology, including molecular tests to detect DNA of human papillomavirus are methods used in the diagnosis of this pathology. Can be considered complementary tests between yes, since they form part of the protocol for the study of women with cervical lesions and each has a special indication. The Pap smear and colposcopy have been used over the years with the objective of diagnosing the affections pre-malignant and malignant lesions of the uterine cervix; however, the histological study is the one that is conclusive in order to establish the definitive diagnosis (Dzul-Rosado K.R., 2004).

The colposcopy is considered a more sensitive technique, less specific and higher cost than cytology for the detection of disease cervical pre-invasive. Its use can significantly reduce the percentage of false negatives of cytology (Zahm D. M, et al., 1998) (Reyeroa J.C and Navierob J.S., 
2004). As all method, the colposcopy has limitations; one of them is the age of the patients, since in the postmenopausal women the europeanescamocolumnar tends to be entered in the endocervical canal, making it difficult to its assessment, resulting in a 6 per cent of false negatives and up to $18 \%$ colposcopías unsatisfactory(Aguilar Pérez, et al., 2003) (Serrano et al., 2012).

The report of the results of the examination of colposcopíco, the description of the injuries and diagnostics are issued on the basis of the Official Mexican Standard NOM 0014 SSA 1997 updated to 2007 for the prevention, detection, diagnosis, treatment, control and epidemiological surveillance of uterine cancer (NOM-014SSA2-1994., 1998).

The cytology, colposcopy and biopsy have become complementary systems for patients with cervical pathology (Aguilar Pérez J.A., et al., 2003).The combination of 2 tests improves the predictive values. With the prevalence of the study, cytology and a biopsy positive have a positive predictive value of $97 \%$. With the likelihood that a woman with colposcopy and cytology positive has a $92 \%$ chance of having a neoplasia and with these 2 same tests negative, $91 \%$ not submitted, without arriving in any case to diagnose or rule out fully the disease (Reyeroa J.C. \&Navierob J.S., 2004). On the contrary, this situation has not been observed in developing countries, as is the case of Mexico, where in 1974 was implemented the National Program for the early detection of cancer (PNDOC), and in spite of this, the mortality rate for $\mathrm{CC}$ during the past 25 years has not diminished, due to the low coverage and quality (Aguilar Pérez J.A., et al., 2003).

The quality of the programs of early detection of cervical cancer is governed in Mexico in the Official Mexican Norm 014SSA2-2007 (Linaldi-Yépez F. 2010). In Mexico there is a high morbidity and mortality by cc due to social disparities. It has been observed that the place of residence, ethnic group, socioeconomic level and access to social security, among other factors, are associated with women who suffer cc, other factors are the beginning of sexual relations at early ages, before the age of 20; early pregnancy, by the immaturity of the cells of the neck; The multiparity, due to the trauma during childbirth; the frequent change of partner with the unprotected sexual activity of the couple; sexually transmitted infections, smoking, for increased concentration of nicotine in the cervical mucus; oral contraceptives, nutritional deficiencies, genetic factors as the deficit of alpha 1-antitrypsin that have a protective effect on the epithelium of the cervix, the HPV viruses are classified with high and low risk depending on the degree of invasion linked with cancer are: HPV 16, $18,31,45$ and 58 in a study on global distribution of the types of virus, identified the HPV 16, 18, 31, 58 and 52 as the first five viruses involved in cervical cancer, in Central America the prevailing HPV 31. (Serrano, 2012).

It is very important to the work of research and for this awareness, in patients and health personnel, for regular vaginal cytology, in order to make an early diagnosis in a period where the lesions are intraepithelial neoplasia, avoiding its progression to invasive cancer. The cytology, is performed by exfoliation of cells from the cervix, its microscopic observation, governed by the Bethesda system classifies the pre-neoplastic lesions in high and low grade malignancy, but has a high percentage of false negatives and therefore low sensitivity (Torriente Hernández S.I.et al., 2011). 


\section{Clinical Case}

A female patient of 40 years of age who come to review gynecological, he says to the Doctor. Having detected balls between the anus and the lips genitals when bathing and the sensation of having role there. During the anamnesis mentions having sex a previous month and be his first relationship, the patient is Christian.

\section{Doctor: Do Observed Something rare in your Partner?}

Patient: if, in the pubis note some wartsand you ask why, looking for the cause; he answered that used a product for alopecia and that the chemical splatteredin that area. I accepted the response and had relations. The Doctor to explore detects 2 small warts, commanded (citología cervical con técnica de papanocolaou?) study of papanicolaou and gives you appointment to do electrofulguration, giving as presumptive diagnosis HPV, since the day of the appointment starts your menstrual period, this treatment is not performed. Requests another appointment in the ISSSTE for a second opinion, the day of the appointment, after the scan the doctor emits the same diagnosis, after structuring the clinical history, explain to the patient that it is not possible that a chemical produces a reaction well in the skin, a chemical is not going to generate warts and in that moment it performs the papanicolaou and electrofulguration; lets you open appointment for any problem or doubt that may be present and recommends that you talk with your partner to go to consultation and carry out fault finding and provide specific treatment.

The patient returns home, feeling a little pain, discomfort when walking and psychically damaged; communicates with your partner to inform you of the situation, to which the answers:

Couple: I am not sick!, Who did you get?, to which she responds: You know that you were the only and the diagnosis I confirmed two doctors.

Days after gathers results of papnicolaou, that showed no alteration, he continued appearing to your appointments for review.

The year returns to feel the emergence of a single "bolita" (nodule), smaller than the first time; again is presented with the doctor and he performed again electrofulguration and the application of a cream "Argentafil every 8 hours for 5 days. Phemeday apply with the bathroom, furthermore he sends performed studies in molecular biology, to know which of the 3 types of virus is, since there are viruses oncogenic and these high pathogenicity, associated epidemiologically with the appearance of cervical-uterine. Your result is not indicates the presence of the viruses 16 and 18, which are the types that cause most of the cancers in the cervix.

\section{Results and Discussion}

At present there is no effective treatment $100 \%$ to cure this type of infections, so it is necessary to remain in constant medical surveillance to prevent the evolution to diseases such as cancer cervico-uterine, dependent of other risk factors, such as what is smoking or high consumption of alcohol, multiple sexual partners among others. The patient noted in his speech not having had sexual relations with other couples, this equal is unknown by your partner, the fact is that the infection by HPV are characteristically warts, although there are those who do not are taking the infection, this type of infections are more likely in people who have multiple partners or sex 
with high-risk groups, the patient in his speech, said not to have had sexual partner before this person, it is likely that your partner at least had had sexual relations with other women and that this is infecting and I do not seek professional help medical. The consequences of having relations with a person infected with the human papilloma virus, could be shot by the immune system, but in those where the immune system is not exterminate the virus, its effect can be not only at the physical level, but to psychological level with impact on his emotional state, impact to moral level and in some way this clinical case is striking for the society, as no person is exempt from getting a sexually transmitted infection, regardless of age, sexual experience, the physical condition, degrees of studies or religion.

In some cases to get to know a person, we think that it is the one with which we will live the rest of our days, without knowing whether the sexual behavior of this and if this keeps sexual intercourse with multiple partners, even without using protection, feel free to have relationships when so decides, puts at risk their physical integrity and the will of the one who thought that relationship would be lasting and with responsibility, but in their desire to feel free and with null, or little commitment autogenera their risks and their partner, in this case also highlights the said that which can more the hormone that the neuron.

This case is manifested in the interview narrated-by the person affected and it denotes that it did not have the necessary knowledge to say, no, not at the moment where the attributes the warts to a product that does not cause this effect on the skin, even that is in definitive impossible that that would have occurred as an accident arising from exposure in two anatomical regions distant, as is the head "is for alopecia" and inguinal region including the penis so that, in addition denotes irresponsibility, both by not attending the doctor to seek help when you started with the problem, such as when she informed him come to medical consultation.

All of the above is associated with risk factors involved (Serrano L.D., et al., 2012), but the case leaves the possibility of considering the sexual behavior, the need to work in the health sector with education programs for health, but especially considering the constructivist approach to education, where the main effect rests on the awareness, i.e. that the person aware of their state of health and which could have an impact on the other person, including the risks to have contact with multiple partners, including groups of risk. A said that I instituted and I consider it pertinent to think two or a thousand times have sex without responsibility "faces we see, genitals do not know", that is, before the immense variety of sexually transmitted infections, including HPV and AIDS, is to teach us to think and act with responsibility.

In conclusion, the patient is today carrier asymptomatic Human Papilloma Virus HPV, impacted in the emotionally, physically and morally. The relationship with the partner that you contagion culminated in bad terms, since it was left pending the diagnosis of their partner and therefore does not give notice of his state of health-disease to their previous or current couples, must inform their partners their status if you decide to have sex again. If you decide to get pregnant, you must have a delivery by cesarean section, to avoid contagion and should continue in review on a regular basis during two years.

\section{Acknowledgments}

To the person who shared his case with the sole purpose of which is to assess how 
important it represents the sexuality with responsibility and that work is performed from the education for health. Likewise to Mancilla Tenorio Alondra Yanelliand Trejo Rivera Itzel, for his collaboration in the translation of the manuscript into English for the disclosure of the same.

The authors declare that there is no conflict of interests for the publication of this article.

\section{References}

Aguilar Pérez, J.A., Leyva López, A.G., Angulo Nájera, D., Salinas, A.y Lazcano Ponce, E.C. 2003. Tamizaje en cáncer cervical: conocimiento de la utilidad y uso de citología cervical en México. Rev. Saúde Pública, 37(1): 100-6.

AhmedinJemal, D.V.M., Bray, F., Center, M.M., Ferlay, J., Ward, E., Forman, D. Global Cancer Statistics. CA Cancer J. Clin., 61:69-90.

DOI: 10.3322/caac.20107.

Broso, P.R., Buffetti, G. 1993. The Papanicolaou classification in the Bethesda System. National Cancer Institute, Bethesda, Maryland. Minerva Ginecol, 45: 557-63.

Cox, J.T. 1995. Lorincz A, Shiffman MH, Sherman ME, Cullen A, Kurman RJ. Human papilloma virus testing by capture appears to be useful in triaging women with a cytologic diagnosis of atypical squamous cells of undetermined significance. Am. J. Obstet. Gynecol., 172: 946-54.

Cox, J.T. 1999. Evaluating the role of HPV testing for women with equivocal Papanicolaou test findings. JAMA, 281: 1645-7.

Dzul Rosado Karla, R., Puerto Solís Marylin, González Losa María del, R. 2004. Cáncer cervicouterino: métodos Actualespara su detección. Rev.
Biomed., 15: 233-241. Recuperado el 26 de agosto, 2014; Disponible en http://www.uady.mx/sitios/biomedic/r evbiomed/pdf/rb041545.pdf

Graham. F.J.C. 2014. Colposcopia. Revista del Instituto Nacional de Cancerología. Disponible en: http://www.incan.org.mx/revistaincan/ elementos/documentosPortada/124097 5174.pdf

Hadzic, B., Hadzic, M,. Curcin, N. 1999. Histologic classification and terminology of precancerous lesions of the cervix. Med. Pregl., 52: 151-5.

LinaldiYépez, F., HernándezCruz, L., ApresaGarcía, T., HernándezHernández, D.M., Martíez Torres, J. 2010. Indicadores de calidad en la detección oportuna de cáncer cervicouterino en unidades de primer nivel de atención. Rev. Medica del Instituto Mexicano del Seguro Social, 48(3): 243-252.

Reyeroa, J.C., Navierob, J.S. 2004. Evaluación diagnóstica de la citología, la colposcopia y la biopsia en mujeres con sospecha de lesiones precursoras de neoplasia cervical intraepithelial. Salas Progreso Obstetricia $y$ Ginecología, 47(4): 155-61.

Sánchez Barriga, J.J. 2012. Tendencias de mortalidad por cáncer cervicouterino en las siete regiones socioeconómicas y en las 32 entidades federativas de México en los años 2000-2008. Secretaría de Salud. Dirección de Investigación Operativa en Epidemiología. Dirección General Adjunta de Epidemiología., México, D.F. Gaceta Médica de México, 148: 42-51.

Secretaría de Salud. 1998. Norma Oficial Mexicana para la prevención, tratamiento y control de cáncer del cuello del útero y de la mama en la atención primaria. Hospital General de 
México. Disponible en: www.hgm.salud.gob.mx/servmed/nom _014_ssa2_1994.pdf

Serrano, L., D., Millán, Vega, M.M., Fajardo Tornés, Y., Sánchez Alarcón, C. 2012. Lesiones preinvasivas del cuello uterino. Revista Cubana de Obstetricia y Ginecología, 38(3): 366377. Recuperado en 17 de mayo de 2016 , http://scielo.sld.cu/scielo.php?script=s ci_arttext\&pid=S0138$600 X 2012000300009 \& \operatorname{lng}=\mathrm{es} \& \ln g=\mathrm{e}$ $\mathrm{s.}$

\section{How to cite this article:}

Mónica Luz Cabrera López, Verónica Rodríguez Galicia, Patricia Vázquez Alvarado, Diana Verónica Sánchez Martínez, Jesús Carlos Ruvalcaba Ledezma. 2016. HPV Positive. I am not sick!, Who did you get? Its Impact on the Health of the Patient. Int.J.Curr.Microbiol.App.Sci. 5(6): 612-618. doi: http://dx.doi.org/10.20546/ijcmas.2016.506.066 